\title{
In memoriam: Emeritus Professor Laksiri Dharmasoka Jayasuriya (1931-2018)
}

\author{
Siri Gamage \\ School of Social Science and Psychology, Western Sydney University, Parramatta, Australia. \\ Department of Sociology, Faculty of Arts, University of Peradeniya, Peradeniya, Sri Lanka.
}

Emeritus Professor Laksiri Jayasuriya who was a Professor of Social Work and Social Administration at the University of Western Australia passed away on April 20 2018 in Perth. He was the founder of the Sociology Department of the University of Colombo and led an illustrious career in the Australian academia while contributing to government policy making in areas such as multiculturalism, ethnic affairs, immigration and citizenship. He nurtured cohorts of students under his care during his long career in Australia and continued to engage in scholarly activities and publishing after retirement. Professor Jayasuriya leaves behind beloved wife Rohini and two loving sons Kanishka and Pradeep -both professionals- one in the academia and the other in medical field. His death comes as a great loss to his academic colleagues, particularly in Australia and Sri Lanka.

Laksiri was born on $27^{\text {th }}$ October 1931 in Ceylon, during the late British colonial period, as the eldest in a family of three. He obtained primary and secondary school education from Royal College, Colombo (19451951). This was an institution that trained civil servants for the colonial government of Ceylon. Thus, he grew up as a member of the English educated elite in Ceylon and came from a privileged background. He was in the debating team in the Royal College which also included figures like Felix Dias Bandaranayake (later a Minister of Finance and Public Administration) and Mervin de Silva (a reputed journalist). During the War, a school named Glendale moved to the hills and he was schooled in its residential facility for four years. It instilled British tradition and values in him while affording the opportunity to participate in sports. There, he edited Glendale Gazette and took part in a mock parliament (Jayasuriya, 2002).

Following the trend at the time of the English educated elite to send children for higher studies in Cambridge or Oxford, he also wanted to follow the same path. However, through an encounter with Professor A. P. Elkin, father of Peter Elkin, an English professor at the University of New England, Australia, on his visit to Colombo, the opportunity arose for Laksiri to go to Australia for tertiary education. He proceeded to Sydney by a ship called Himalaya in 1951 to begin his studies as a private student and became a resident of the Wesley College. At Sydney, he was with a cohort of students who occupied influential positions later in Australia and overseas (Jayasuriya, 2002). He studied for a Bachelor's Degree in Psychology (Hons) between 1951-54 at the University of Sydney obtaining the degree in 1954 with First Class and the University Medal.

He brought with him a leftist orientation and political consciousness from his Royal College days. Sri Lanka (then Ceylon) had a strong Trotskyite Group at the time. He had a close relationship with David Ross - a senior student at Wesley and the son of a Communist Party Trade Unionist. His contemporaries included Hedley Bull - who became Professor of International Relations and Jim Wolfensohn, who became President of the

${ }^{*}$ Corresponding author (gamage.siri@yahoo.com; (iD https://orcid.org/0000-0003-2503-8585)

Original Source: Gamage, S. (2018) Obituary: Emeritus Professor Laksiri Dharmasoka Jayasuriya (1931-2018), Social Affairs: A Journal of the Social Sciences, 1(8), pp. 56-59.

Copyright 2018 by Social Affairs: A Journal of the Social Sciences. Published with permission. 
World Bank. His teacher Prof. W. M. O'Neil had much influence on him in terms of 'scholarship and academia than anyone else' (Jayasuriya, 2002).

The group of people Laksiri was interacting with at Sydney University was well aware of the need for Australia to engage with Asia. He gained considerable understanding through involvement in university life: E. g. President of the Sydney University Psychological Society (1953), Secretary of the Sydney University International Club (1953), President of Sydney University Anthropology Society (1952-53). He orgainsed one of the initial Sydney film festivals. Later, he was to continue this interest in film when he took up his appointment at the University of Ceylon, as it was then called. His work for Radio Australia called 'Diary of an Asian Student' which documented his response to or reflections on Australian life was notable. In the 1950s, he received several prizes including Frank Albert Prize and a University Gold medal.

Laksiri studied subjects such as history, psychology and anthropology. After completing the Bachelor's degree in 1954, he was offered a Teaching Fellowship in the same year by the Sydney University. He was a pioneer Asian academic at Sydney University. Laksiri was 23 years of age then. Most students he taught were returned servicemen who were in a different age group. He taught a first-year statistics course. Teaching lasted until the end of 1955 (Jayasuriya, 2002).

Laksiri accepted a fulltime, permanent academic appointment at the University of Ceylon, Peradeniya in 1956. Having trained as a social psychologist, he joined the Sociology Department which at that time included Ralph Pieris, Stanley Thambiah and Gananath Obeyesekera. At the time, the Department was very well regarded within the university system in Sri Lanka. The campus was a site of creative intellectual endeavour as well as of robust intellectual curiosity over academic and political issues. Laksiri built strong friendships with people such as K. N. Jayatilleke- Professor of Philosophy and J. E. Jayasuriya - Professor of Education. He was an active participant in the academic debates and is remembered fondly by his colleagues and students.

Laksiri pursued postgraduate studies at the London School of Economics and Political Science between 1957-60, securing his PhD in Social Psychology. He lectured in the Departments of Psychology and Social Work. In 1969, he became the Foundation Professor in the Department of Sociology and Social Welfare, University of Colombo and developed the academic program within the Department. He was particularly proud of establishing the workers education program in Colombo. Laksiri returned to Sydney in 1969 on a Leeverhulme Fellowship to the University of New South Wales. This was after his time at Berkley on a Fulbright Scholarship. In 1974, Laksiri was appointed as Foundation Professor in the Department of Social Work and Social Administration (later Social Work and Social Policy) at the University of Western Australia, Perth. He was the first Asian professor there and one of the first Asians to be appointed to a professorial position at an Australian University.

During his academic career in Perth, he held the positions of Head of Department (1971-90) and Director, Centre of Asian Studies (1989-92). Between 1970-71, he was the Dean of Social Sciences. He was a Fellow of the British Psychological Society and the Australian Academy of Social Sciences and an Honorary member of the Australian Association of Social Workers. He became an emeritus professor and a Senior Honorary Research Fellow at the same university in 1993, marking the end of his active full-time teaching and research career. During 1993-94, he served in the capacity of a Senior Fellow in Development Studies at Edith Cowan University, Perth. He was never one to slow down. He continued his academic work after retirement in association with the University of Western Australia in an honorary capacity until his health started to deteriorate. The energy and enthusiasm he showed on the subjects that he grappled with was extraordinary. He was truly blessed with an intellect and a vast reservoir of knowledge covering both the Eastern and Western social philosophies.

In the 1970s, 1980s and 1990s Laksiri played an active role in various State and Federal Government advisory bodies and reviews in Australia dealing with areas such as multicultural education, language services and ethnic affairs. He was appointed to the Immigration Advisory Council by the Whitlam Labour government. During 1973-75, he was on the Federal Government Committee on Community Relations as well as the Migrant Taskforce of the West Australian Government. He was the Chair of the National Advisory and Coordinating Committee on Multicultural Education (NACCME) (1984-87) and the National Multicultural Advisory Council (NMAC) (1996-97). Laksiri served on the Anti-Racism Reference Group of the West Australian Government (2001-2007). These positions highlight some of the key points of his significant contribution to policy making, review and advisory services. In those capacities he was able to elevate himself to be a spokesperson for the immigrant and ethnic communities whose needs and interests had to be looked after by way of government policies and programs. He was one of the key architects of the multicultural policy in Australia. His policy and academic contributions emphasised the importance of a political 
conception called 'pluralistic citizenship' as opposed to a narrow conception of 'cultural diversity' associated with cultural, linguistic or ethnic identity.

Laksiri's Academic career at the University of Western Australia was a highly productive one in terms of teaching, supervision of postgraduate students, research and publications (1971-1993). He served on various Editorial Boards of reputed journals such as the Australian Journal of Social Issues, Contemporary Social Work Education, Journal of Multicultural Social Work, and the Journal of Population. He was a member of the Australian Population Association, British Sociological Association, Australian and New Zealand Sociological Association and Australian Association of Social Workers. He was an Elected Fellow in the Academy of the Social Sciences in Australia and the British Psychological Society. In recognition of his community and public service, he received Member of the Order of Australia Award (AM) from the Government of Australia in 1984.

In the 1980s and 1990s, Laksiri published papers and books on contemporary policy issues. He co-edited a book on Legacies of White Australia: Race, Culture and Nation (2005) and another book titled Transforming a White Australia: Issues of Racism and Immigration (2012). There are a significant number of book chapters, occasional papers and journal articles to his credit. During his long and fruitful career, he published books, monographs and articles focused on Sri Lanka, dealing with social development, as well as Welfarism and Politics in Sri Lanka (2000). The latter is a book used by postgraduate students researching about the way Sri Lanka turned away from welfare government to one based on a neoliberal, free market economic paradigm.

In the later stage of his life, Laksiri focused on Buddhist Philosophy, in which his father also had shown a keen interest by publishing a book. Laksiri published an article on Buddhist Humanism for the Asian Century in the International Journal of Buddhist Thought and Culture (2011) and a book titled Reflections on Buddhist Social Philosophy (2014). He had a keen interest in electoral politics in Sri Lanka also and he analysed election results after national elections and published papers in 2001 and 2002.

A significant part of his academic work examined issues of social policy and electoral politics in Sri Lanka. He was particularly interested in the way social policies helped to shape new patterns of class formation and conflict in Sri Lanka. His book Taking Social Development Seriously (2010) was a synopsis of many of his key ideas on these issues. He was interested, and disappointed in the way neoliberal policies over the last decades dismantled or impoverished some of these programs.

Laksiri was asked to give the prestigious guest of honour address on the sweeping victory of the Sri Lanka Freedom Party (SLFP) in 1970. This led to a very productive series of publications on Sri Lankan elections until 2010 and its broader social context. He published a book on The Changing Face of Electoral Politics in Sri Lanka (2005). Two of his important contributions to Sri Lankan studies are The Sri Lankan Welfare State: Retrospect and Prospect published by Edith Cowan University (1996) and Welfarism and Politics in Sri Lanka: Experience of a Third World Welfare State published by the School of Social Work and Social Policy, University of Western Australia, Perth (2000).

Laksiri was the founding President of West Australian Buddhist Society. He assisted Asian students through Australia-Asia House at the University of Western Australia in numerous ways.

His published work is available online through the National Library of Australia for anyone to access. It is a fitting tribute to a tireless academic, advocate on immigrant and ethnic rights, policy advisor, a humanist and influential figure in the Australian policy context. Condolence messages received from the West Australian Government and former ministers of Multicultural Affairs etc. reflect his standing in the Australian community. $\mathrm{He}$ was a giver as one of his friends has remarked in the Guest Book maintained by the The West Australian newspaper.

Laksiri is fondly remembered as an intellectual rooted in Sri Lanka but based in Australia, writing with integrity representing the interests of those on the margins in Australian society in the context of social theory, government social policy, ethnic rights, equity and social justice.

May he rest in peace!

\section{REFERENCES}

Jayasuriya, L. (2002) Interviewed by David Walker for National Library of Australia, $12^{\text {th }}$ November [Online] Available from: https://laksirijayasuriya.files.wordpress.com/2014/08/lj-davidwalker-interview1.pdf [Accessed: $3^{\text {rd }}$ May 2018].

Jayasuriya, L. (2004) Personal and Professional BiographyLaksiri Jayasuriya [Online] Available from: https:// laksirijayasuriya.com/ [Accessed: $3^{\text {rd }}$ May 2018]. 